\title{
Pasebaya Agung as a Disaster Information Media Innovation to The Community in Karangasem Regency, Bali Province
}

\author{
Ida Ayu Putu Sri Widnyani ${ }^{1}$, Gede Wirata ${ }^{2}$, Sri Sulandri ${ }^{3}$ \\ dayusriwid@gmail.com
}

Ngurah Rai of University Denpasar Bali

\begin{abstract}
The purpose of this research was to determine the effectiveness of the Pasebaya Agung organization (Pasemetonan Jagabaya Mount Agung) as a medium of communication in overcoming disasters in Karangasem regency. The research method used descriptive qualitative with purposive sampling technique in determining informants to conduct interviews. This organization is an innovation of media policy in providing clear information related to disasters in Karangasem Regency. This communication media uses $146,800 \mathrm{Mz}$ of handy talk (HT) with ORARI (Radio Republic of Indonesia organization) frequency which can be accessed easily by the entire community of Karangasem Regency even reaching beyond Karangasem. Evidenced by the eruption on July 28, 2018 which is quite large, the news contained in social media can be overcome. Communities by listening to information from the Pasebaya Agung channel can be controlled and the community becomes calm because of the information obtained by Valid from one source.
\end{abstract}

Keywords: Policy, Media, Information, Pasebaya Agung, and Disaster.

\section{Introduction}

The experience in the disaster in Karangasem Regency, the Mount Agung eruption case at the end of 2017 looks less ready. Intention occurred on Friday September 22, 2017 is one factor that is not clear information. The amount of information from social media by uploading images that did not really confuse the Karangasem people who wanted to flee out Karangasem Regency. What should have been affected by refugees is that there are people who do not want to evacuate, while those who want to evacuate do not know where to evacuate. Many families are separated from family members. According to residents "it was really tense, the traffic was very chaotic, for a few days Karangasem City and villages like dead cities without trade, without people were just howls of wandering dogs.

The eruption several times, the trauma of the feeling and panic of the people is not clear. Starting from this incident, a group of residents meeting a was a communication forum in providing information about the condition of Mount Agung. Why do they want to do an analysis of the objectives of the forum and what are the benefits of the forum formed related to the disaster of Mount Agung. Then what is the role of the local government of Karangasem Regency with this institution. 


\section{Method}

This study uses a qualitative descriptive research method. The qualitative research intended by Strauss and Corbin as a type of "research whose findings are not obtained through statistical procedures or other forms of calculation. Examples can be in the form of research about a person's life, history and behavior, as well as about the role of the organization, social movements or reciprocal relations" [1].

Based on the opinion of Strauss and Corbin above, it means that this research method is appropriate because it analyzes innovative model communication about mitigation eruption of mount Agung at Karangasem Regency. Determination of informants using purposive sampling, and data collection techniques through documentation, interviews and data search on line. The qualification of informans is Pasebaya leader, society, local government..

\section{Result}

Pasebaya Organization (Pasemetonan Jaga Baya) Mount Agung was formed and declared on Friday, November 17, 2017. The history of the formation of Pasebaya Agung over the call of conscience 28 Perbekel in the area of KRB (Disaster Prone Area). The idea emerged from the Perbekel (Village Heads) in the area who had been busy taking care of their residents to flee. The idea was facilitated by the Regional Disaster Management Agency (BPBD) Chief of Karangasem Regency Ida Bagus Ketut Arimbawa by holding several meetings at the Disaster Response Post at the Tanah Ampo Banjar Land Pier Building, Ulakan Village, Manggis District. So the producers agreed to form the Pasemetonan Jagabaya.

The aim was to reduce the impact of the Mount Agung eruption disaster, anticipate the threat of disasters in 28 villages, prevent the occurrence of casualties by optimizing communication between Perbekel in the field. The Pasebaya Agung Declaration was confirmed by the Head of BNPB Rear Admiral Willem Rapangilei accompanied by Director of Community Empowerment BNPB Raditya Jati, Secretary Local Government of the Karangasem Regency I Gede Adnya Muliadi, and Dandim Lt. Col. Inf Benny Rahadian in the hall of the Karangasem Regent Office. Before the declaration, a short-term program had been arranged regarding the importance of communication in 28 affected villages internally.

Furthermore, each bundle must socialize to its citizens, the importance of evacuating immediately if Mount Agung begins to erupt. Pasebaya Agung also maps affected villages and evacuated routes. So that the case of Friday September 22, 2017 was not repeated as soon as Mount Agung was declared an alert status, residents immediately panicked and confused looking for a place to evacuate.

Pasebaya Agung will map the number of residents complete with names and determine the place of refuge. Then coordinate with the destination village. The next step is to establish cooperation between the affected villages and buffer villages. So that, as refugees arrive, the buffer village is ready to accept. Chairman of the Pasebaya Agung (Pasemetonan Jagabaya Gunung Agung or standby disaster Mount Agung Family) was entrusted to I Gede Pawana (East Duda Perbekel, Selat District), Deputy Chair I Wayan Potag (Ban Perbekel, Kubu Subdistrict), Secretary I Wayan Suara (Amerta Bhuana Perbekel, Selat Subdistrict) and Treasurer I Wayan Waskita (Perbekel Jungutan, Bebandem Subdistrict) Besides having a member group, Pasebaya also has volunteers who have community radio in 28 villages. 
The positive response of the Karangasem Regency Local Government, BNPB and BPBD to the Pasebaya Agung Organization, will facilitate training in order to have high preparedness and resilience in the face of the Mount Agung eruption, especially for 28 affected villages. It is hoped that the Pasebaya institution will be the front guard in providing information to convince the public, if residents must evacuate.

Media in conveying information by Pasebaya Agung to the public using community radio or handy talk (HT), previously still hitched on the ORARI (Radio Republic of Indonesia Organization) frequency and now has a special frequency in the number $146,800 \mathrm{Mz}$. The reason for choosing HT media because of the signal can reach the corners of the village even to the hills and to the lowest level of society.

The constraints faced by Pasebaya Agung institutions are still limited to community radio owners. However, "to overcome the limitations of radio media, the suppliers share information to residents through having the habit of gathering every evening in the banjar (hall meeting) to listen to information from other regions" [2].

The process of delivering information about the condition of Mount Agung to the community: on Monday November 27, 2017 At 06.00 the time of the Status of Mount Agung in the Province of Bali has been raised to level IV. The community is recommended to evacuate from the dangerous zone by the Center for Volcanology and Geological Disaster Mitigation (PVMBG). This information was quickly provided to community radio of Pasebaya. Through these radio channels, they are conveyed to the public through their respective from Perbekel. Every time information about the condition of Mount Agung is monitored by Pasemetonan Jagabaya (Pasebaya) Mount Agung actively through radio communication or handy talky (HT) to provide information on the conditions in each village.

Through the Pasebaya Agung community information about the conditions of the eruption of Mount Agung became one way. Information can be trusted to be accurate and updated. Because when there is information about something and the situation in the village level administrative area, before being broadcast it will be checked first to the location. "Another network in providing information also through the WhatsApp application" Nurul Hikmah [3].

The Pasebaya Agung community is expected to educate the public about the potential danger of eruption, exchange information, provide assistance and even information through this unlimited forum regarding the condition of Mount Agung but also information about other disasters. Communities outside Karangasem Regency can also access information through channels owned by Pasebaya Agung.

The phenomenon that has occurred and has been carried out by the people of Karangasem Regency and includes the support of local government and other organizations is one of the innovations initiated by the community by forming an institutional called Pasemetonan Jagabaya (Pasebaya) Mount Agung. [4] mentions innovation in governance "can be an initiative to improve governance mechanisms that bring together government authority and the influence of society in one arena of public decision making".

Innovation initiated by the community has a purpose as a medium of information to the community that is formed in a complete institution complete with organizational structure, the Pasebaya Agung institution in accordance with Institutional theory revealed [5], namely:

"institution represents a social order or pattern that has attained a certain state or property; an institution is then a social pattern that reveals a particular reproductions process". Because Pasebaya Agung is a social organization, it is not profit oriented, it only produces clear, precise, accurate and up-to-date information to the public. 
Information innovation initiatives formed in the Pasebaya Agung Institute as a media of information trusted by the public must obtain legality by the government, such as the opinion of Rose and Davies (1994) in [6] stating "some public agencies have more influences than others. They also use loosely coupled procedures which may contradict or conflict. the public sector is structured around asymmetric power relationships". As a public institution that must always maintain public trust, members should maintain an attitude like the opinion of [7] about "public agencies provide moral and cognitive frameworks which allow themselves to be as good as third parties to make sense of events and to act in specific circumstances. They supply information. They also shape the identity, the image of self-preference and administrative behavior".

The information that has been conveyed by the Pasebaya Agung institution to the community is felt to be very beneficial by the community, because this information can be trusted by the community, because of the many social media that convey false or hoax information. It has been proven that eruptions have occurred several times and there have been forest fires on the slopes of Mount Agung whose news that the great volcano erupted by issuing fire and lava did not panic the people. The efforts made by Pasebaya Agung can be optimally needed by cooperation between stakeholders institutions including the Local Government of Karangasem Regency along with ranks, BPBD of Karangasem Regency, Center for Volcanology and Geological Disaster Mitigation (PVMBG), Security such as soldier National of Indonesia and Police Republic of Indonesia (TNI and Police), community leaders and Pasebaya Agung. Cooperation between these institutions is very important so that the direction of information is one track. Collaboration between institutions is very necessary because of the limitation of authority and the existence of one information so as not to overtake the information received by the community. This is in accordance with Bevir's statement [8].

The traditional concept of the policy process entailed a single sovereign actor with legal jurisdiction over a substantive policy arena pursuant to a defined delegation of authority. However, hierarchy's command and control management strategies failed in the face of problems that could not be solved or solved easily by one entity acting alone. Moreover, hierarchy failed entirely as an approach to global and transnational problems, i.e those that cross the jurisdictional boundaries of nation-state. these developments have given rise to the concept of governance rather than government. governance entails activity among multiple actors with potentially overlapping jurisdiction.

Fredirickson reinforces the statement of [9] "observed that public administration is moving toward theories of cooperation, networking, governance, and institutional building and maintenance in response to jurisdiction and public management in a fragmented and disarticulated state".

The result of research [10] "is that there are two type of communication in communities around Mount Kelud, namely the activities of Community Radio and Informal Socialization. The community is aware that there are dangers lurking glue them every day and have the initiative to establish a community radio as an alternative to deliver information about the latest status of Kelud. Informal Socialization activities carried out because the government can not reach out and provide information quickly and precisely to the entire community".

[9] too research the results showed that "local government disaster preparedness in managing people with disability is by integrating prioritizing and opening participation for people with disability in every starts from assessment, planning, institutional framework, information system, resource base, warning system, response mechanism, education, socialization and simulation. In the future, local government should raise the awareness of 
disability in every level of community to create positive communication between stakeholders in disasters and empower people with disability as volunteers that able to communicate effectively with the diversity of disability". So [10] has research "the results show that artificial factors/human influence caused environmental damage, and there is a need to establish policies that govern unconventional mining and supervision of tin mining activities".

\section{Conclusion}

The conclusions from the description of community innovation in mitigating the disaster of the Mount Agung eruption are: the importance of information conveyed to the community through one way given government legality so that important information can be received clearly, accurately and up to date. It is very important to open cooperation from various parties in disaster mitigation. Innovation can be initiated by the community and supported by the government and related stakeholders. The Pasebaya institution is very beneficial for the community, especially the Karangasem Regency Community. There are still limited facilities and infrastructure in the form of communication tools owned by Pasebaya Agung members and volunteers. Limited communication media so that information is delivered directly every afternoon when residents gather in the banjar namely (hall meeting).

Recommendations that can be submitted in this paper are: 1) innovation not only from the government but from any party can provide ideas for the benefit of the community; 2) in implementing the idea of innovation, it needs the support of all parties through cooperation between institutions which of course the role of local government is very dominant in providing facilitation and legality; 3) the model of the Pasebaya Agung institution needs to be replicated elsewhere for management in the face of disasters both before and post-disaster from the aspect of communication; 4) the support of facilities and infrastructure by various parties to optimize the performance of the Pasebaya Agung institution.

\section{References}

[1] S. a. Corbin, Dasar-Dasar Penelitian Kualitatif Tata Langkah dan Teknik-Teknik Teoritisasi Data. Yogyakarta: Pustaka Pelajar.

[2] H. Gunawan, "Pasebaya Penyambung Informasi untuk Kesiapsiagaan Warga Gunung Agung," 29.

[3] N. Hikmah, "Radio Komunitas Pasebaya Jadi Penyambung Informasi untuk Kesiapsiagaan Warga Gunung Agung," 29.

[4] S. H. Sj., Partisipasi dan Inovasi Good Governance 20 Prakarsa Inovatif dan Partisipatif di. Indonesia, Jakarta: Yayasan Obor.

[5] P. a. Dimaggio, The New Institutionalism In Organizational Analysis. London: The University of Chicago Press, Ltd.

[6] P. a. Pierre, The Handbook of Public Administration, London ECIY. ISP: SAGE Ltd. [7] B. Mark and Governance, London ECIY. ISP: SAGE Ltd.

[8] T. E. B. S. K, “Fitta Amellia L.A, „Communication As An Effort To Disaster Risk Reduction For Society (Disaster Risk Reduction Study With System Dynamics Of Keludees Eruption, East

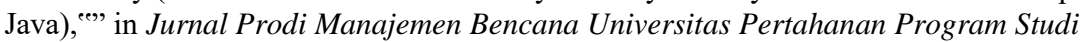
Manajemen Bencana Untuk Keamanan Nasional, vol. III, vol. 1, pp. 1-21. 
[9] R. Wulandari, “„The Analysis Of Local Government Preparedness In Managing People With Disability To Face Earthquake Disaster, "Jurnal Prodi Manajemen Bencana Universitas

Pertahanan Program Studi Manajemen Bencana," in Untuk Keamanan Nasional, vol. III, vol. 1, pp. 1-19.

[10] Y. HS, “,Analysis Of Impact Unconventional Tin Mining To Flood (Studies In Pangkalpinang City The Province Of Bangka Belitung 2016), "Jurnal Prodi Manajemen Bencana Universitas Pertahanan Program Studi Manajemen Bencana," in Untuk Keamanan Nasional, vol. III, vol. 1, pp. 1-17. 